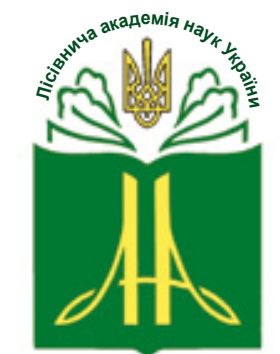

Forestry Academy of Sciences of Ukraine
Наукові праці Лісівничої академії наук України

Proceedings of the Forestry Academy of Sciences of Ukraine

\author{
http://fasu.nltu.edu.ua \\ https://doi.org/10.15421/411924 \\ Article received 2019.07.14 \\ Article accepted 2019.12.26
}

\author{
ISSN 1991-606X print \\ ISSN 2616-5015 online \\ (a) $\square$ Correspondence author \\ Kateryna Davydenko \\ kateryna.davydenko74@gmail.com \\ Pushkinska str., 86, Kharkiv, 61024, Ukraine
}

UDK 630.4

\title{
Evaluation of fungal endophytes to biological control of Dothistroma needle blight on Pinus nigra subsp. pallasiana (Crimean pine)
}

\author{
K. Davydenko'
}

Dothistroma needle blight (DNB), caused by Dothistroma septosporum and Dothistroma pini, is the most important forest disease of pine in many countries. This disease has recently emerged in Ukraine as a major threat to mostly Pinus nigra subsp. pallasiana and less to Scots pine. There is increasing evidence that some fungal and bacterial isolates can reduce the growth and pathogenicity of fungal plant pathogens.

In this research, infected needles were collected from 30-year-old Crimean pine ( $P$. nigra subsp. pallasiana) in four locations in Southern Ukraine. In total, 244 of endophytic fungi were recovered from needles of Crimean pine during summer sampling of the host's microbiome in Ukraine in 2012-2014.

Dothistroma spp. were detected using fungal isolation and species-specific priming PCR techniques.

Among all endophytes, eight fungal species were selected based on the commonness of their occurrence in the foliage of the host and their antagonistic activity. All selected species were tested for their antifungal activity against Dothistroma needle blight. Good antifungal activity against Dothistroma pini was achieved with the Trichoderma sp. and Gliocladium rosea, indicating their good potential possibility in preventing the Dothistroma needle blight on young pines. Moreover, the significant reduction in numbers of conidia and spore germination was found on needles treated with Trichoderma sp. and Gliocladium rosea, compared to conidia numbers following treatment with other fungi. Thus, the use of an effective biological control agent against Dothistroma could be of value in forest nurseries, where it is essential to reduce losses to D. pini infection prior to transferring pines to field sites for planting out.

Key words: DNB; Dothistroma septosporum; Dothistroma pini; pathogens; biological control; forest health.

Introduction. Dothistroma needle blight (DNB) is one of the most serious needle diseases of pine plantations and is responsible for many economic losses in landscape and forest settings through negative impacts on yields, quality of stands and visual amenity.
The main symptoms of the disease are premature needle fall, reduce in photosynthetic capacity, followed by yield losses and, in some cases, tree mortality (Bradshaw 2004, Woods et al. 2005, Millberg et al., 2016). Two closely related ascomycetous fungi are

Kateryna Davydenko - Corresponding Member of the Forestry Academy of Sciences of Ukraine, PhD, (agricultural sciences), senior researcher, G. M. Vysotsky Ukrainian Research Institute of Forestry \& Forest Melioration, Pushkinska str., 86, Kharkiv, 61024, Ukraine. Visiting Researcher at Department of Forest Mycology and Plant Pathology, Uppsala BioCenter, Swedish University of Agricultural Sciences, P.O. Box 7026, SE-75007, Uppsala, Sweden. Tel.: +38-098 66755 26. E-mail: kateryna.davydenko74@gmail.com ORCID http://orcid. org/0000-0001-6077-8533 
known to cause DNB: Dothistroma septosporum (Dorogin) M. Morelet and D. pini Hulbary (Barnes et al., 2004). Dothistroma septosporum and D. pini do not show consistent differences in the length of their conidia, so it is necessary the use of specific molecular markers for their discrimination and identification of the two pathogens (Barnes et al. 2004, Ioos et al., 2010).

Dothistroma septosporum has a worldwide distribution and found in many parts of the world where pines are grown (Barnes et al., 2008, Bulman et al., 2013). D. pini was found from some countries in Europe including Ukraine and from the USA (Drenkhan et al., 2016).

Dothistroma septosporum was first recorded in the Kiev region (Smela town) of Ukraine on Pinus sylvestris L. by L. Kaznowski (Barnes et al., 2008). Since 2004, DNB outbreak has been reported several times in the Tsjurupinsk (Kherson region) and Mykolaiv region on 30-year-old Crimean pine (P. nigra subsp. pallasiana or P. pallasiana, or P. nigra var. pallasiana (D. Don in Lamb) resulted in massive pine dieback in the southern Ukraine (Usichenko \& Akulov 2005, Drenkhan et al., 2016). The natural range of P. nigra subsp. pallasiana covers the southern Carpathians and the Crimean Peninsula in Ukraine, as well as the Balkan Peninsula, Cyprus, the Black sea coast of Caucasus and Turkey (Barnes et al., 2008, Lazarević et al., 2017). Outbreak of DNB has spread in southern Ukraine and south-western Russia devastating more than 8000 ha of pine forests (Usichenko \& Akulov, 2005).

Presently, DNB occurs throughout southern Ukraine and its severity appears to be increasing (Drenkhan et al., 2016) alongside climate change. It may act together with native or invasive pathogens and reduce the populations of Crimean pine (Tubby and Webber 2010, Adamson et al., 2018).

As DNB affects over 80 species of Pinus, as well as other conifers (Watt et al., 2005, Drenkhan et al., 2016), there is an urgent need to find effective methods for disease control and management, because DNB resulted in the rejection of planting susceptible Pinus species in some countries of Africa, Asia, Australasia, Europe and North America (Bulman et al., 2016). The main practices used to control of DNB in Ukraine are early detection of symptoms and signs of DNB, pathogen population monitoring. No chemicals applied in the Ukrainian forest due to the lack of permissible fungicides. However, copper and other fungicides were applied in the forest and landscape nurseries for pathogen spread prevention to uninfected areas, as well as an elimination of infected seedlings. According to Bulman et al. (2016), DNB may be effectively controlled using copper fungicides as it routinely applied in New Zeeland and Australia, or by planting non-susceptible species, as is the most common form of management in Europe. Only a few studies demonstrated the possibility of using biological control agents to reduce the impact of this highly damaging pathogen in forest tree nurseries (Allenzi et al., 2015).
The aim of the study was to find potential biological agents against Dothistroma needle blight. This study reports the following results: i) screening needle endophytes to search potential agents of biological control against pine needle pathogen Dothistroma pini; ii) artificial inoculation experiments to test the potential of two fungal strains to provide control of Crimean pine infection by $D$. pini.

Objects and methods. Fungal isolates and plant material. Several endophytic fungi were recovered from needles of Crimean pine during summer sampling of the host's microbiome in Ukraine in 2012-2014. Asymptomatic, healthy needles were collected from trees growing in the Kherson region $\left(46^{\circ} 31^{\prime} 36.2^{\prime \prime} \mathrm{N}\right.$ $32^{\circ} 32^{\prime} 01.3$ ”'E). Fifty individual needles were sampled in the canopy from each of ten trees of Crimean pine for a total of 500 needles. Needles were surface-sterilized by serial sterilization ( $1 \mathrm{~min}$ in $95 \%$ ethanol, $5 \mathrm{~min}$ in $6 \%$ sodium hypochlorite $(\mathrm{NaOCl})$, and $30 \mathrm{~s}$ in $95 \%$ ethanol) before plating onto $3 \%$ potato dextrose agar (PDA). Smaller sample groups were also taken from diseased pines that appeared to have lower disease severity. The hyphal tip of each morphologically different mycelium that emerged from a needle was subcultured and transferred to for later identification. Following incubation, fungal isolates recovered from each plant fragment were selected at random, purified and grouped based on phenotypic characteristics, e.g. colony morphology, colony colour, and growth rate. Isolates representing each fungal group of interest were selected for further identification by morphological traits (classic taxonomy) and/or rDNA sequencing.

Dothistroma pini was isolated from infected needles collected in 2012-2014 in southern Ukraine (Kherson region, $\left.46^{\circ} 31^{\prime} 36.2^{\prime \prime} \mathrm{N} \quad 32^{\circ} 32^{\prime} 01.3^{\prime \prime} \mathrm{E}\right)$, and was used in artificial inoculation experiments previously. Following recovery from the plant tissues, representative cultures of dominant genera were made according to morphotypes and stored at $4^{\circ} \mathrm{C}$ on PDA.

Selection of endophytic fungi antagonists to Dothistroma pini. Fungi were selected based on the commonness of their occurrence in the foliage of the host and their antagonistic activity. The in vitro selection of antagonists against $D$. pini was carried out on $8 \%$ malt extract agar (MEA) medium a pairedgrowth assay. For this, mycelial discs $(5 \mathrm{~mm})$ of $D$. pini were inoculated on Petri dishes $(100 \mathrm{~mm})$ containing MEA medium and incubated at $28^{\circ} \mathrm{C}$ (photoperiod of 12 hours). Due to the slow growth of $D$. pini, after 15 days, the endophytic microorganisms were inoculated $50 \mathrm{~mm}$ from $D$. pini colony. The ability of a root endophyte to antagonize the pathogen was determined based on the inhibition level over a given period of time. This was achieved by assessing and measuring the concurrent growth of both the endophyte and the pathogen simultaneously on a shared MEA nutrient media surface (Fig. 1).

The inhibitory effect of each fungal endophyte on the pathogen is reflected in the spherical index $(\alpha / \beta)$ of the respective organisms (Rigerte et al., 2019). Solitary 
cultures of the respective endophyte and the pathogen were also plated - and observed - as controls in this experiment. The antagonism was detected also by the formation of an inhibition halo (Fig. 2). For dual-culture assay the null hypothesis was formulated as follows: the difference between the means of the spherical indices of pathogens under antagonism and the means of the spherical indices of pathogen controls zero (Rigerte et al., 2019). The alternative hypothesis was formulated as follows: the difference between the means of the spherical indices of pathogens under antagonism and the means of the spherical indices of pathogen controls is less than zero (Rigerte et al., 2019). The rationale for assuming this alternative hypothesis was that the spherical index of the pathogen under antagonism would be less than one $(<1)$ while the controls, having grown in the absence of any biotic/abiotic pressure(s), should have a spherical index $\approx 1$ (Rigerte et al., 2019).

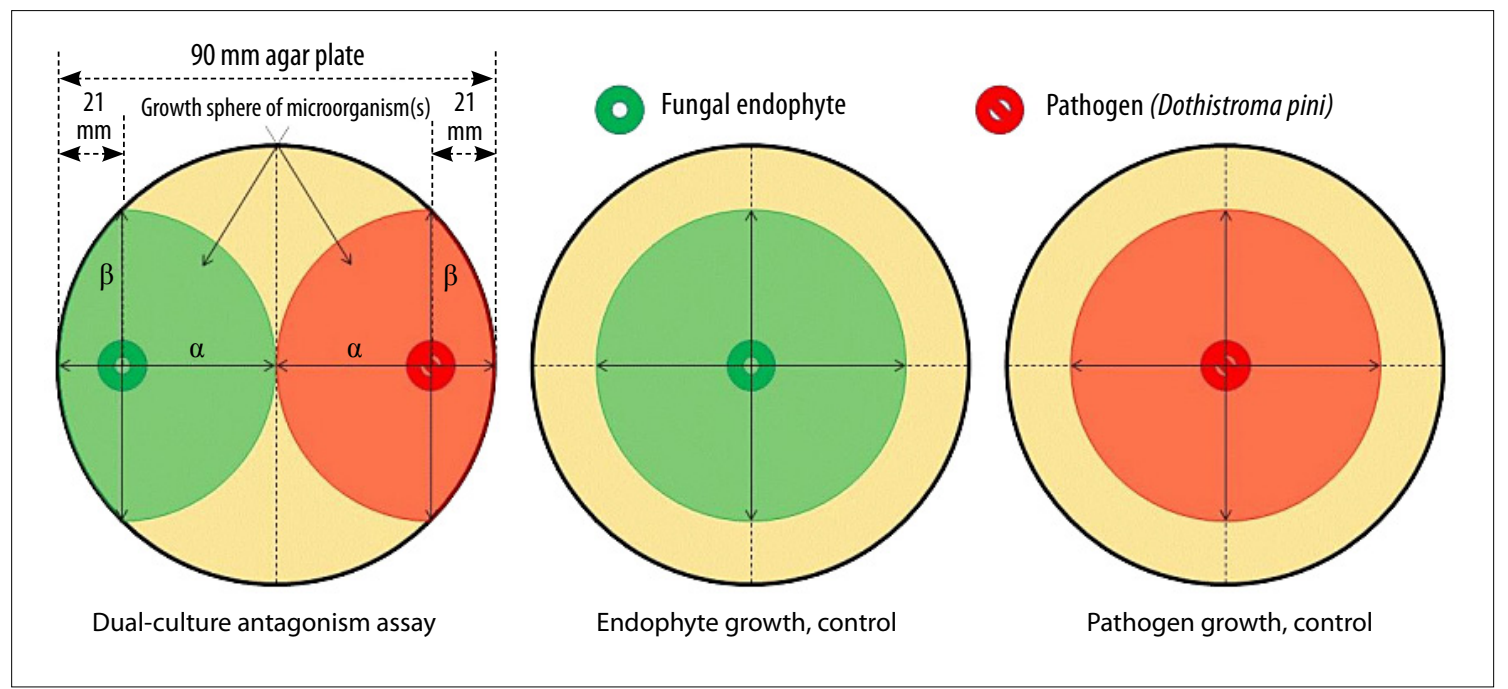

Figure 1. Schematic overview of the dual-culture antagonism assay tests (Rigerte et al., 2019)
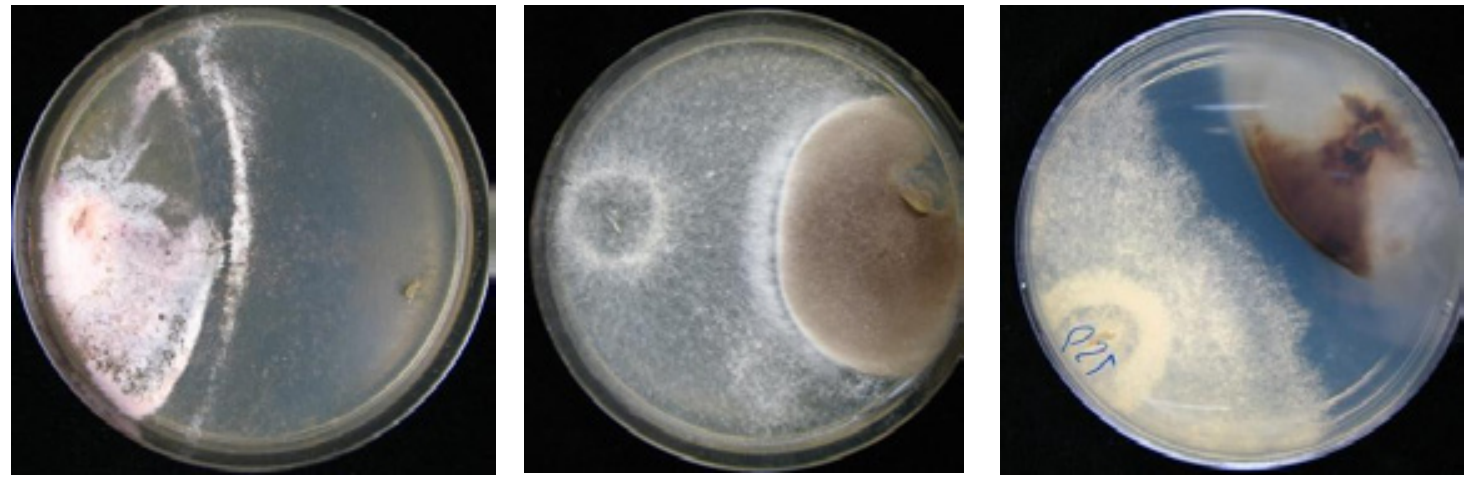

Figure 2. The selection of endophytic antagonists to Dothistroma pini based on the formation of inhibition halo

Thus, if the effect of specific endophyte is real, then the means would also record the same behaviour, and the subtraction of the means of controls from the pathogen replicates involved in the test would then be a negative number (Rigerte et al., 2019).

Plant material and fungal inoculation in planta. Two-year-old Crimean pine (P. nigra subsp. pallasiana) seedlings were grown from seeds in the State Forest Enterprise "Holoprystanske LG" Kherson region. Five hundred seedlings without any symptoms of DNB were replanted in the nurseries at the Forest Protection Service enterprise "Kharkivlysozahist" (Kharkiv region, Ukraine) in March, 2017 for inoculation experiment.

A single plate of a mature culture of each selected fungus was used to obtain inoculum. To generate inoculum, approximately $20 \mathrm{ml}$ of sterile distilled water was added to each Petri dish with mature culture and loosening the spores into suspension by passing sterile glass beads over the surface of the culture, yielding a spore density of from $3 \times 10^{4}$ to $7.3 \times 10^{9}$ cells $(\mathrm{CFU})$ $\mathrm{ml}^{-1}$ (Tab. 1). Conidial suspensions were adjusted to c. $1 \times 10^{4}-1 \times 10^{9}$ spores $\mathrm{ml}^{-1}$ following replicate haemocytometer counts.

All suspensions were made to a volume of $200 \mathrm{ml}$ with sterile distilled water and placed to the different spray bottles.

All pure cultures of eight selected fungi were made on MEA and PDA.

A solution of $200 \mathrm{ml}$ of sterile distilled water was also included as a control. Concentrations of spores were not standardized across treatments since the fungi 
were so diverse and their interactions with the host and the pathogen could not be expected to be comparable.

In July 2017, P. nigra subsp. pallasiana seedlings were assigned to inoculation treatments with eight endophytic fungi, with 20 replicate plants per treatment. For in planta testing for $D$. pini antagonists, 10 days after inoculation of endophytic fungi, spores of $D$. pini were introduced into the seedlings. For each treatment, the foliage was sprayed with a hand-held atomiser until large droplets formed. Control plants were inoculated just with sterile distilled water.

To stimulate DNB development, free water was maintained on needle surfaces. For this, plants were sprayed twice a day with water for 7 days. These incubation conditions were modified from Fraser et al. (2016) and were designed to be optimum for the development of DNB.

The symptoms were evaluated from 60 to 120 days and the data were statistically analyzed by the one-way variance ANOVA method (test compared the means). After 60 days, five needles were collected randomly from each of five plants within each treatment group to determine the fungal inocula loads and percentage conidial germination. Four months after inoculation with $D$. pini, all needles of the previous year were collected and inspected under a microscope. DNB severity was assessed by calculating the percentage of needles with $D$. pini conidiomata. DNB severity was evaluated using the assessment system of Schwelm et al. (2009).

Table 1

\section{Approximate propagule concentrations per $\mathrm{ml}$ of selected fungi suspension for testing their antagonistic activity}

\begin{tabular}{lcc}
\hline \multicolumn{1}{c}{ Species } & Medium for cultivation & Spore concentration in suspension \\
\hline Cladosporium sp & MEA & $1.8 \times 10^{6}$ \\
\hline Gliocladium roseum & MEA, PDA & $2.9 \times 10^{4}$ \\
Ilyonectria sp. & MEA & $2.7 \times 10^{8}$ \\
Sydowia polyspora & MEA & $1.9 \times 10^{6}$ \\
Trichoderma sp.1 (Lithuanian isolate) & MEA, PDA & $7.3 \times 10^{9}$ \\
Trichoderma sp.2 (needle endophyte) & MEA & $6.2 \times 10^{8}$ \\
Unidentified Ascomycetes 23 & PDA & $2.3 \times 10^{5}$ \\
Unidentified Ascomycetes 37 & PDA & $3.7 \times 10^{6}$ \\
\hline
\end{tabular}

* - One Trichoderma sp. strain was obtained from the Environmental Sciences culture collection, Natural Research Centre (Vilnius, Lithuania) showing string activity against pine pathogens in artificial inoculation experiments previously.

Molecular detection and identification. DNA was extracted from the selected symptomatic needles representing groups of different treatments. To avoid contamination on the needle surface, needle samples were washed in $96 \%$ ethanol for 60 seconds, $2 \%$ sodium hypochlorite for 5 minutes and rinsed in $96 \%$ ethanol for 30 seconds. Needles were transferred to a screw cap tube together with a screw and two nuts, freeze-dried and homogenized using a fast prep shaker (Precellys 24 Bertin Technologies). DNA was extracted following a CTAB protocol. Briefly, $1 \mathrm{ml}$ of CTAB was added to each sample and incubated for one hour at $65^{\circ} \mathrm{C}$. Samples were centrifuged and the supernatant was transferred to new tubes and cleaned with chloroform. DNA was precipitated with isopropanol, washed with $70 \%$ ethanol and eluted in $50 \mathrm{ml}$ of milliQ water. After DNA extraction, samples were cleaned using JetQuick DNA purification kit (Genomed $\mathrm{GmbH}$ ) and the concentration was measured with a NanoDropTM (Thermo Scientific).

Conventional PCR with species specific primers was used to detect $D$. septosporum and $D$. pini in the needles, using species-specific primers DStub2-Forward (CGAACATGGACTGAGCAAAAC) and DStub2-
Reverse (GCACGGCTCTTTCAAATGAC), and DPtef-Forward (ATTTTTCGCTGCTCGTCACT) and DPtef-Reverse (CAATGTGAGATGTTCGTCGTG), respectively (Ioos et al. 2010). The PCR reaction contained $200 \mathrm{mM}$ deoxyribonucleotide triphosphates, $0.2 \mathrm{mM}$ of each of the two primers, $0.0265 \mathrm{u} / \mathrm{ml}$ DreamTaq polymerase with 10X DreamTaq Green Buffer (DreamTaq Green, Thermo Scientific, Waltham, $\mathrm{MA}$, USA) and $\mathrm{MgCl} 2$ at a final concentration of $3.25 \mathrm{mM}$. The PCR conditions included an initial denaturation step at $95^{\circ} \mathrm{C}$ for $10 \mathrm{~min}$ followed by 35 amplification cycles of denaturation at $95^{\circ} \mathrm{C}$ for $30 \mathrm{~s}$, annealing at $60^{\circ} \mathrm{C}$ for $30 \mathrm{~s}$ and extension at $72^{\circ} \mathrm{C}$ for $1 \mathrm{~min}$, and thermal cycling was ended by a final extension step at $72^{\circ} \mathrm{C}$ for $10 \mathrm{~min}$. The PCR products were purified with Qiagen DNA extraction PCR M kit (Qiagen, Hilden, Germany). PCR products were size separated on $1 \%$ agarose gels and visualized under UV light to confirm the presence of the 231 bp D. septosporum specific bands and 191 bp D. pini specific bands (Ioos et al. 2010).

Statistical analyses. Statistical analysis was carried out using the software JMP ${ }^{\circledR}$, Version 11.0.0. SAS Institute Inc., Cary, NC, 1989-2007. Data were 
statistically analyzed by the one-way variance method and the Tukey-Kramer multiple comparison. Test compared the means. One-way ANOVA tests were used to assess the impact of treatment on DNB severity. If ANOVA tests were significant, post-hoc Tukey tests were used to identify which treatments differed significantly. DNB severity was log-transformed before analysis. The impact of treatment on conidial germination was assessed with Kruskal-Wallis U-tests and post hoc Mann-Whitney U-tests with Holm corrections.

Results and discussion. The diversity of endophytic fungi was assessed in healthy (Site 1 and 2) and symptomatic (Site 3 and 4) trees of Crimean pines.
To avoid contamination and to isolate endophytic fungi only from inner needle tissues, surface disinfection was applied. The endophytic fungal community which was isolated from needles included Alternaria sp., Cladosporium sp., Colletotrichum sp., Diaporthe sp., Dothistroma sp., Fusarium sp. (including Gibberella avenacea), Gliocladium sp., Lophodermium sp., Mariannaea elegans, Sordariomycetes sp., Trichoderma sp. mostly (Tab. 2). The number of most common and fast-growing endophytic fungi that were recovered using MEA and PDA medium was not significantly different within both categories of plants (healthy and symptomatic) evaluated.

Table 2

Pooled relative abundance of selected most common fungal taxa obtained from asymptomatic and symptomatic needles collected on Crimean pine grown in south Ukraine (Kherson region)*

\begin{tabular}{|c|c|c|c|c|}
\hline Fungal taxa & $\begin{array}{c}\text { Site } 1 \\
\text { healthy trees }\end{array}$ & $\begin{array}{c}\text { Site } 2 \\
\text { healthy trees }\end{array}$ & $\begin{array}{c}\text { Site } 3 \\
\text { symptomatic trees }\end{array}$ & $\begin{array}{c}\text { Site } 4 \\
\text { symptomatic trees }\end{array}$ \\
\hline 1 & 2 & 3 & 4 & 5 \\
\hline \multicolumn{5}{|c|}{ Ascomycota and other species } \\
\hline Alternaria sp. & 2.17 & 2.1 & 0 & 6.94 \\
\hline Aspergillus versicolor. & 0.5 & 2.52 & 2.1 & 2.3 \\
\hline Bionectria sp. & 5.33 & 5.2 & 4.17 & 3.47 \\
\hline Botryotinia fuckeliana & 5.14 & 8.9 & 1.2 & 3.5 \\
\hline Cadophora sp & 0.1 & 0.5 & 0.42 & 0.25 \\
\hline Chaetomium globosum & 1.3 & 1.2 & 1.6 & 2.51 \\
\hline Chaetomium sp. & 2.1 & 1.05 & 2.52 & 3.13 \\
\hline Cladosporium sp. & 1.2 & 2.1 & 5.25 & 2.52 \\
\hline Cladosporium herbarum & 2.2 & 2.52 & 6.33 & 5.25 \\
\hline Cladosporium sp & 10.42 & 5.25 & 19.6 & 9.74 \\
\hline Cordyceps sp. & 4.17 & 0 & 5.14 & 6.60 \\
\hline Colletotrichum sp. & 5.14 & 1.05 & 2.52 & 0.1 \\
\hline Cyclaneusma niveum & 0.9 & 1.3 & 5.5 & 2.15 \\
\hline Dothistroma pini & 0.1 & 0.3 & 24.5 & 52.3 \\
\hline Dothistroma sp & 1.05 & 2.52 & 5.25 & 1.05 \\
\hline Diaporthe sp. & 0.01 & 12.5 & 6.8 & 0.01 \\
\hline Gibberella avenacea & 18.75 & 15.6 & 10.42 & 17.3 \\
\hline Gliocladium roseum & 7.25 & 5.25 & 8.15 & 2.3 \\
\hline Eupenicillium sp. & 7.6 & 1.3 & 8.33 & 5.21 \\
\hline Fusarium oxysporum & 2.08 & 0.2 & 0.1 & 3.13 \\
\hline Fusarium $s p$ & 0.05 & 4.17 & 0.1 & 2.43 \\
\hline Ilyonectria sp & 8.8 & 2.08 & 4.25 & 8.33 \\
\hline Lophodermium seditiosum & 4.75 & 4.17 & 6.3 & 9.03 \\
\hline Mariannaea elegans & 9.5 & 6.8 & 2.2 & 2.52 \\
\hline Penicillium sp & 0.01 & 4.17 & 0.9 & 4.86 \\
\hline Penicillium roqueforti & 0.5 & 0.1 & 0.1 & 1.74 \\
\hline Phoma sp & 0.1 & 0.1 & 4.17 & 5.21 \\
\hline Phomopsis sp. & 0.3 & 0.1 & 0.1 & 0.1 \\
\hline
\end{tabular}




\begin{tabular}{lcccc}
\hline \multicolumn{1}{c}{1} & 2 & 3 & 4 & 5 \\
\hline Pleosporales sp. & 2.1 & 0.1 & 2.2 & 5.6 \\
Sordariomycetes sp. & 7.9 & 0.1 & 2.3 & 5.6 \\
Sydowia polyspora & $\mathbf{1 3 . 0 0}$ & $\mathbf{1 9 . 5}$ & $\mathbf{1 5 . 9}$ & $\mathbf{1 5 . 4}$ \\
Trichoderma like asperellum & $\mathbf{1 2 . 3}$ & $\mathbf{1 5 . 8}$ & $\mathbf{6 . 3 5}$ & $\mathbf{1 5 . 6}$ \\
$\quad$ Unidentified fungi & & & & \\
Uncultured Ascomycetesclone H23 & $\mathbf{1 5 . 6}$ & $\mathbf{1 4 . 3}$ & $\mathbf{9 . 2}$ & $\mathbf{1 0 . 5}$ \\
Uncultured Ascomycetes clone H37 & $\mathbf{7 . 9}$ & $\mathbf{5 . 1}$ & $\mathbf{8 . 6}$ & $\mathbf{9 . 7}$ \\
Unidentified Basidiomycota FG14 & 0.1 & 0.1 & 0.1 & 0.1 \\
Unidentified Basidiomycota FG39 & 0.1 & 0.1 & 0.1 & 0.1 \\
Fungal sp HN18 & 0.1 & 0.1 & 0.1 & 0.1 \\
Fungal sp HN19 & 0.1 & 0.1 & 0.1 & 0.1 \\
Unidentified culture M12 & 0.1 & 0.1 & 0.1 & 0.1 \\
Unidentified culture M74 & 0.1 & 0.1 & 0.1 & 0.1 \\
\hline
\end{tabular}

* - fungi for antagonistic tests were selected based on the commonness, so only species common for all four sites were included in the Tab. 2.

A total of 244 endophytic fungi isolated from needles were randomly picked up and this population was partially characterized by rDNA (partial 18S, ITS-1, 5.8S, ITS-2 and partial 23S) sequencing. The results (see Tab. 2) showed that the most common and fast-growing endophytic fungi associated with the Crimean pine belong mainly to Ascomycetes group (Fig. 3) being the Botryosphaeriaceae, Diaporthacea, Dothideacea, and Capnodiaceae families the most frequent. The fungi Fusarium spp. and Cladosporium spp. were the dominant genera and showed the highest diversity (see Tab. 2). No correlation between fungal groups and plant categories was observed. The frequency of fungi isolation was 0.54 and 0.75 for healthy and symptomatic plants, respectively.

Partial sequences of rDNA were aligned and the relationships between endophytic isolates were evaluated by a neighbour-joining algorithm (see Fig. 3). Using this strategy, some isolates could not be identified. Cladosporium sp. was the most common genus recovered from needles. Both Sydowia and Trichoderma spp. as well as two unidentified species were also recovered at high frequency in Dothistromainfected foliage sample and visually healthy needles. Given these findings, seven commonly isolated fungi from the microbiome of Crimean pine, including Gliocladium roseum (anamorph, Clonostachys rosea) (see Tab. 1, 3) and Bionectria sp. were selected and employed as putative disease modifiers.

Clonostachys rosea is a known parasite and antagonist of other fungi (Moraga-Suazo et al., 2011) and the genus Bionectria includes destructive mycoparasites, some of which are used as biocontrol agents of fungal plant pathogens (Schroers, 2001). One Trichoderma sp. strain was obtained from the Environmental Sciences culture collection, Natural Research Centre (Vilnius, Lithuania) showing high activity against pine pathogens in artificial inoculation experiments previously. So, a total of eight endophytic fungi were evaluated in vitro and in vivo against $D$. pini.
Only two species were able to inhibit the growth of the causal agent of Dothistroma needle blight of Crimean pine in vitro and two in planta (Tab. 3).

Dothistroma needle blight severity expressed as the percentage of needles with conidiomata was significantly lower on plants treated only with Trichoderma sp. 1 and Gliocladium roseum than trees treated with either species. In contrast, DNB severity on plants treated with other fungi was not significantly different from that on plants treated with $D$. pini. No conidiomata were observed on control plants treated with purified water.

At 120 days after $D$. pini inoculation, conidial density on needles from plants treated with both Trichoderma sp. 1 and Gliocladium roseum was significantly lower than on plants treated with either antagonistic fungi (Tab. 4). There was no significant difference between the other fungal species and positive treatments in conidial density or germination at either time point. Although conidial density appeared to increase between days 60 and 120 , this increase was not significant (paired t-test, $\mathrm{p}>0.05)$.

Overall, disease severity varied significantly by a tree (see Tab. 3), where the tree represents the combined effects of tree resistance and fungi impact. Severity varied significantly from tree to tree from as little as $1.7 \%$ to as much as $18.1 \%$. Modifying effects were strongly significant $(\mathrm{P}<0.0001)$, as were their interactions with trees $(\mathrm{P}<0.0001)$ (Tab. 5).

It has previously been shown that endophytic communities vary spatially in the plant or may be dependent on the interaction with other endophytic or pathogenic microorganisms (Allenzi et al., 2015). Moreover, plant susceptibility to DNB is often related to the stress level of the individual and stress can arise from mismatching of the planting stock's ecological traits to the planting site, root deformities, damage, and desiccation, planting at improper depths in unsuitable soils, poor nutrient and water availability, and increased 
exposure to pollutants, xenobiotics and contaminants (Bulman et al., 2013, 2016). So, these endophytic fungi are ubiquitous and may increase the plant resistance by improving tolerance to drought, reducing the phytopathogen settling and promoting plant growth (Allenzi et al., 2015).

Table 3

Impact of potential antagonistic fungal species treatments on Dothistroma pini isolates growth and on DNB disease severity on Crimean pine needles

\begin{tabular}{|c|c|c|c|c|}
\hline \multirow{2}{*}{ Inoculation treatments } & \multirow{2}{*}{\multicolumn{2}{|c|}{ Inhibition halo, $\mathrm{mm}$}} & \multicolumn{2}{|c|}{ Disease severity, $\% \pm \mathrm{SE})^{*}$} \\
\hline & & & agonistic fungi & Dothistroma pini \\
\hline Bionectria sp & \multicolumn{2}{|c|}{$32.5^{\mathrm{a}} \pm 2.9$} & + & $17.95 \pm 0.1^{\mathrm{a}}$ \\
\hline Cladosporium sp & \multicolumn{2}{|c|}{$14.2^{\mathrm{b}} \pm 1.4$} & + & $18.11 \pm 0.5^{\mathrm{a}}$ \\
\hline Gliocladium roseum & \multicolumn{2}{|c|}{$24.2^{\mathrm{c}} \pm 2.8$} & + & $1.71 \pm 0.2^{\mathrm{b}}$ \\
\hline Sydowia polyspora & \multicolumn{2}{|c|}{$15.3^{b} \pm 1.9$} & + & $17.22 \pm 0.3^{\mathrm{a}}$ \\
\hline Trichoderma sp.1 & \multicolumn{2}{|c|}{$29.8^{\mathrm{d}} \pm 1.8$} & + & $2.31 \pm 0.4^{\mathrm{b}}$ \\
\hline Trichoderma sp.2 & \multicolumn{2}{|c|}{$19.2^{\mathrm{e}} \pm 1.4$} & + & $17.41 \pm 0.2^{\mathrm{a}}$ \\
\hline Unidentified Ascomycetes 23 & \multicolumn{2}{|c|}{$14.8^{\mathrm{b}} \pm 1.3$} & + & $17.34 \pm 0.4^{\mathrm{a}}$ \\
\hline Unidentified Ascomycetes 37 & \multicolumn{2}{|c|}{$13.2^{b} \pm 3.4$} & + & $17.58 \pm 0.5^{\mathrm{a}}$ \\
\hline Positive control (D. pini) & \multicolumn{2}{|c|}{-} & - & $8.34 \pm 0.3^{\mathrm{a}}$ \\
\hline Negative control (sterile water) & \multicolumn{2}{|l|}{-} & - & $0 \pm 0$ \\
\hline \multicolumn{5}{|c|}{$\begin{array}{l}* \text { - treatments followed by the same letter do not differ significantly (Tukey, } \mathrm{p}>0.05 \text { ). Negative control plants were excluded from statistical } \\
\text { analysis. }\end{array}$} \\
\hline & & & & Table \\
\hline \multicolumn{5}{|c|}{$\begin{array}{c}\text { Impact of potential antagonistic fungal species treatments on Dothistroma pini conidial density } \\
\text { and germination on Crimean pine needles }\end{array}$} \\
\hline \multirow[b]{2}{*}{ Inoculation treatments } & \multicolumn{2}{|c|}{ After 60 days } & \multicolumn{2}{|c|}{ After 120 days } \\
\hline & $\begin{array}{c}\text { D. pini conidia } \\
\text { density }\left(\text { spores } \mathrm{mm}^{-2}\right. \\
\text { mean } \pm \mathrm{SE})\end{array}$ & $\begin{array}{l}\text { D. pini conidia } \\
\text { germination } \\
(\% ; \text { mean } \pm \mathrm{SE})\end{array}$ & $\begin{array}{c}\text { D. pini conidia } \\
\text { density }\left(\text { spores } \mathrm{mm}^{-2}\right. \\
\text { mean } \pm \mathrm{SE})\end{array}$ & $\begin{array}{l}\text { D. pini conidia } \\
\text { germination } \\
(\% ; \text { mean } \pm \mathrm{SE})\end{array}$ \\
\hline Bionectria ochroleuca & $24.4 \pm 1.3^{\mathrm{a}}$ & $20.5 \pm 10.0^{\mathrm{a}}$ & $26.2 \pm 1.3^{\mathrm{a}}$ & $21.5 \pm 9.0^{\mathrm{a}}$ \\
\hline Cladosporium sp & $19.3 \pm 1.5^{\mathrm{a}}$ & $19.8 \pm 9.2^{\mathrm{a}}$ & $19.8 \pm 1.4^{\mathrm{a}}$ & $20.0 \pm 9.1^{\mathrm{a}}$ \\
\hline Gliocladium roseum & $2.4 \pm 1.2^{\mathrm{b}}$ & $12.8 \pm 6.0^{\mathrm{b}}$ & $2.6 \pm 1.1^{\mathrm{b}}$ & $12.3 \pm 6.5^{\mathrm{b}}$ \\
\hline Sydowia polyspora & $22.1 \pm 0.9^{\mathrm{a}}$ & $24.5 \pm 5.2^{\mathrm{a}}$ & $22.1 \pm 1.1^{\mathrm{a}}$ & $24.9 \pm 5.8^{\mathrm{a}}$ \\
\hline Trichoderma sp.1 & $3.4 \pm 1.2^{\mathrm{c}}$ & $9.4 \pm 6.5^{b}$ & $3.5 \pm 1.1^{\mathrm{c}}$ & $10.4 \pm 6.9^{b}$ \\
\hline Trichoderma sp.2 & $14.8 \pm 3.1^{\mathrm{d}}$ & $19.5 \pm 6.8^{\mathrm{a}}$ & $15.2 \pm 3.1^{\mathrm{d}}$ & $20.2 \pm 6.8^{\mathrm{a}}$ \\
\hline Unidentified Ascomycetes 23 & $20.5 \pm 1.8^{\mathrm{a}}$ & $22.3 \pm 7.3^{\mathrm{a}}$ & $21.0 \pm 1.7^{\mathrm{a}}$ & $23.1 \pm 6.3^{\mathrm{a}}$ \\
\hline Unidentified Ascomycetes 37 & $19.4 \pm 1.8^{\mathrm{a}}$ & $24.5 \pm 6.8^{\mathrm{a}}$ & $19.9 \pm 1.8^{\mathrm{a}}$ & $26.5 \pm 4.8^{\mathrm{a}}$ \\
\hline Positive control (D. pini) & $30.6 \pm 3.2^{\mathrm{e}}$ & $85.9 \pm 6.4^{c}$ & $32.8 \pm 4.2^{\mathrm{e}}$ & $87.8 \pm 6.9^{c}$ \\
\hline Negative control (sterile water) & $0 \pm 0$ & - & $0 \pm 0$ & - \\
\hline
\end{tabular}

Statistical data of modifying effects of antagonistic fungi including tree effect

\begin{tabular}{|c|c|c|c|c|c|c|}
\hline & Source & \multicolumn{2}{|c|}{ DF } & $F$-value & \multicolumn{2}{|r|}{$P$-value } \\
\hline & Treatment & \multicolumn{2}{|c|}{7} & 50.07 & \multicolumn{2}{|r|}{$<.0001$} \\
\hline & Tree & \multicolumn{2}{|c|}{19} & 957.98 & \multicolumn{2}{|r|}{$<.0001$} \\
\hline & Treatment $*$ tree & \multicolumn{2}{|c|}{54} & 104.44 & \multicolumn{2}{|r|}{$<.0001$} \\
\hline$N *$ & Mean DS $\stackrel{* *}{-}$ & Standard deviation & Standard error & $R^{2}$ & $\mathrm{CV} \stackrel{* * *}{=}$ & $N *$ \\
\hline 12.006 & 0.527 & 0.2286 & 0.0013 & 0.4337 & 33.3274 & 12.006 \\
\hline
\end{tabular}




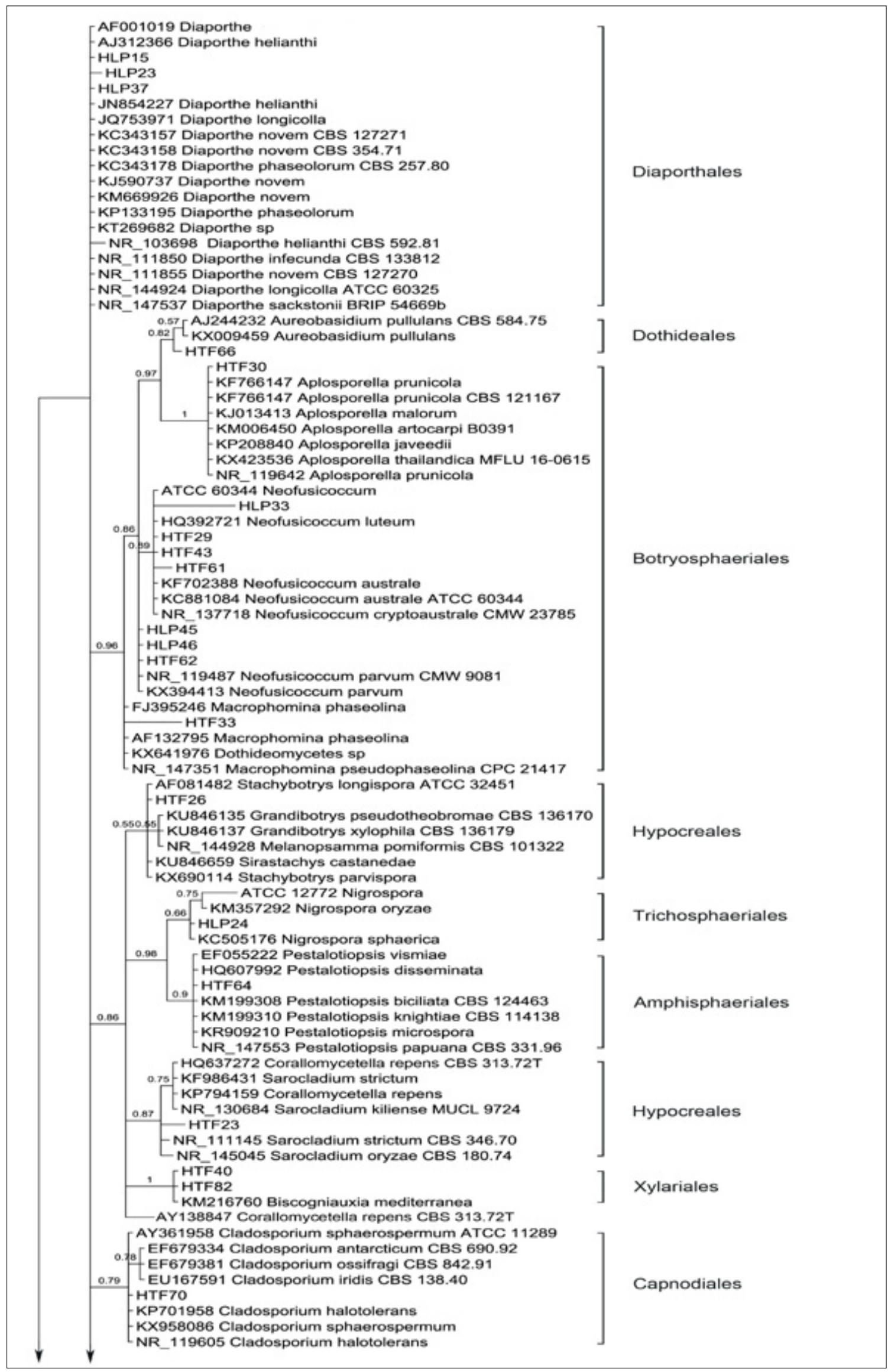

Figure 3. Phylogenetic tree showing the relationship between Crimean pine endophytic fungi and other fungal species. The tree was constructed based on the rDNA (ITS1, 5.8S, and ITS2) fragment sequence by using the neighbour-joining method. The bootstrap analysis was performed with 1000 repetitions 
Current methods for control and management include pruning and thinning of stands to reduce humidity, planting of less susceptible or completely resistant host species and the application of copperbased and other modern fungicides (Bulman et al. 2013). With the exception of a few studies with bacteria, the possibility of using biological control agents to reduce the impact of DNB in forest tree nurseries has received little attention (Allenzi et al., 2015) and this study has increased in importance in Europe for application of biological methods in forest protection.

Plant ecosystems rely heavily on their microbial communities to optimize forest health, although this association might be a good possibility to find a balance between mutualism and disease (Rabiey et al., 2019). Endophytes might cover the capacity to directly inhibit pathogens by producing antifungal compounds (Allenzi et al., 2015, Bulman et al., 2016, Rabiey et al., 2019). Most tests and experiments have carried out in laboratory conditions, but it is unknown how the endophyte-pathogen interaction will alter in the presence of changing environmental conditions and competition with other organisms in the tree system (Rabiey et al., 2019).

Thus, much more field experiment should be taken place to recognize and confirm the optimal time and conditions for usage of biocontrol agents, as climate conditions and tree physiology could alter efficacy and efficiency of biocontrol agents may vary greatly depending on climate and tree traits.

Conclusion. The use of endophytes as biocontrol agents resulted in that Dothistroma needle blight was reduced on Crimean pine seedlings treated with Trichoderma sp. and Gliocladium rosea. The significant reductions in numbers of conidia and spore germination were found on needles treated with Trichoderma sp. and Gliocladium rosea, compared to numbers following treatment with other fungi. Our result suggested that both these species may possess potential in preventing the Dothistroma needle blight at least on young pines.

Although $D$. pini is present almost everywhere Crimean pine is grown, both severity of disease and area of outbreak vary significantly over time and efficiency of the biocontrol agent application may vary greatly depending on climate and tree traits. That's why it is important to continue the search of endophytic biological control agents that may alter the microbial community of the host tree and could decrease DNB virulence or enable host resistance. Further work is required on the impact of the fungal species on Dothistroma infections under nursery conditions.

Acknowledgements. The research was supported by the Ministry of Education and Science of Ukraine within joint Ukrainian-Lithuanian project No M/932018 (Biological control of forest invasive pathogens to preserve biodiversity in European woodland ecosystems). The financial support is gratefully acknowledged from the SI Scholarship of the Swedish Institute (SI) Visby Programme).

\section{References}

Adamson, K., Mullett, M.S., Solheim, H., Barnes, I., Müller, M. M., Hantula, J., ... Drenkhan R. (2018). Looking for relationship between the populations of Dothistroma septosporum in northern Europe and Asia. Fungal genetics and biology, 110, 15-25. https://doi.org/10.1016/j.fgb.2017.12.001

Alenezi, F. N., Fraser, S., Bełka, M., Doğmuş, T., Heckova, Z., Oskay, ... Woodward, S. (2016). Biological control of Dothistroma needle blight on pine with Aneurinibacillus migulanus. Forest Pathology, 46, 555-558. https://doi.org/10.1111/ efp. 12237

Barnes, I., Crous, P.W., Wingfield, M.J., \& Wingfield, B.D. (2004). Multigene phylogenies reveal that red band needle blight of Pinus is caused by two distinct species of Dothistroma, D. septosporum and D. pini. Studies in Mycology, 50, 551-565. Available at: http://www.wi.knaw. nl/images/ResearchGroups/Phytopathology/pdf/ PDF\%20OP\%20NUMMER/201.pdf

Barnes, I., Cortinas, M.N., Wingfield, M.J., \& Wingfield, B.D. (2008). Microsatellite markers for the red band needle blight pathogen, Dothistroma septosporum. Molecular Ecology Resources, 8 (5), 1026-1029. https://doi.org/10.1111/j.1755-0998.2008.02142.x

Bradshaw, R.E. (2004). Dothistroma (red-band) needle blight of pines and the dothistromin toxin: a review. Forest Pathology, 34 (3), 163-185. https://doi. org/10.1111/j.1439-0329.2004.00356.x

Bulman, L.S., Dick, M.A., Ganley, R.J., McDougal, R.L., Schwelm, A., \& Bradshaw, R.E. (2013). 22 Dothistroma Needle Blight. In book: Infectious forest diseases. Croydon: CABI \& CPI Group (UK) Ltd.

Bulman, L.S., Bradshaw, R.E., Fraser, S., MartínGarcía, J., Barnes, I., Musolin, D.L., ... Tubby, K. (2016). A worldwide perspective on the management and control of Dothistroma needle blight. Forest Pathology, 46 (5), 472-488. https://doi.org/10.1111/ efp. 12305

Eschen, R., Roques, A., Santini, A., (2014). Taxonomic dissimilarity in patterns of interception and establishment of alien arthropods, nematodes and pathogens affecting woody plants in Europe. Diversity and Distributions, 21(1), 36-45. https://doi. org/10.1111/ddi.12267

Drenkhan, R, Tomešová-Haataja, V., Fraser, S., Vahalik, P., Mullett, M., Martín-García, J., ... Barnes, I., (2016). Global geographic distribution and host range of Dothistroma species: a comprehensive review. Forest Pathology, 46 (5), 408-442. https:// doi.org/10.1111/efp. 12290

Fraser, S., Martín-García, J., Perry, A., Kabir, M.S., Owen, T., Solla, A., ... \& Vasconcelos, M. W. (2016). A review of Pinaceae resistance mechanisms against needle and shoot pathogens with a focus on the Dothistroma-Pinus interaction. Forest pathology, 46 (5), 453-471. https://doi.org/10.1111/efp.12201 
Ioos, R., Fabre, B., Saurat, C., Fourrier, C., Frey, P., \& Marçais, B. (2010). Development, comparison, and validation of real-time and conventional PCR tools for the detection of the fungal pathogens causing brown spot and red band needle blights of pine. Phytopathology, 100 (1), 105-14. https://doi. org/10.1094/PHYTO-100-1-0105.

Lazarević, J., Davydenko, K., \& Millberg, H. (2017). Dothistroma needle blight on high altitude pine forests in Montenegro. Baltic Forestry, 23 (1), 294 302. Available at: https://www.balticforestry.mi.lt/ bf/PDF Articles/2017-23\%5B1\%5D/Baltic\%20 Forestry $\overline{0}$ 202017.1_294-302.pdf

Millberg, H., Hopkins, A.J.M., Boberg, J., Davydenko, K., \& Stenlid, J. (2016). Disease development of Dothistroma needle blight in seedlings of Pinus sylvestris and Pinus contorta under Nordic conditions. Forest pathology, 46 (5), 515-521. https://doi.org/10.1111/efp.12242

Moraga-Suazo, P., Opazo, A., Zaldúa, S., González, G., $\&$ Sanfuentes, E. (2011). Evaluation of Trichoderma spp. and Clonostachys spp. strains to control Fusarium circinatum in Pinus radiata seedlings. Chilean journal of agricultural research, 71 (3), 412. http://biblioteca.inia.cl/medios/biblioteca/agritec/ NR38113.pdf

Rabiey, M., Hailey, L.E., Roy, S.R., Grenz, K., AlZadjali, M.A., Barrett, G.A., \& Jackson, R.W. (2019). Endophytes vs tree pathogens and pests: can they be used as biological control agents to improve tree health? European Journal of Plant Pathology, 155, 711-729. Available at: https://link.springer.com/ article/10.1007/s10658-019-01814-y

Rigerte, L., Blumenstein, K., \& Terhonen, E. (2019). New R-Based Methodology to Optimize the Identification of Root Endophytes against Heterobasidion parviporum. Microorganisms, 7 (4), 102. https://doi.org/10.3390/microorganisms 7040102 .

Schroers, H.J. (2001). A monograph of Bionectria (Ascomycota, Hypocreales, Bionectriaceae) and its Clonostachys anamorphs. Utrecht: Centraalbureau voor Schimmelcultures

Schwelm A., Barron N. J., Baker J., Dick M., Long P. G., Zhang S., \& Bradshaw R.E. (2009). Dothistromin toxin is not required for Dothistroma needle blight in Pinus radiata. Plant Pathology, 58, 293-304. https://doi.org/10.1111/j.1365-3059.2008.01948.x

Usichenko, A. S. \& Akulov A. Y. (2005). Dothistroma septosporum (teleomorph Mycosphaerella pini) quarantine plant pathogenic fungus revealed in Ukraine. In: Proceedings of the 'Fungi in Natural and Anthropogenous Ecosystems, 1 (pp. 248-253). Sankt-Petersburg: V. L. Komarova Botanical Institute of Russian Academy of Sciences (In Russian).

Woods, A., Coates, K.D., \& Hamann, A. (2005). Is an unprecedented Dothistroma needle blight epidemic related to climate change? BioScience, 55 (9), 761-769. https://doi.org/10.1641/00063568(2005)055[0761:IAUDNB]2.0.CO;2

\section{Оцінювання грибів-ендофітів для біологічного контролю дотистромозу сосни кримської (Pinus nigra subsp. pallasiana)}

\author{
К. В. Давиденко
}

Дотистромоз зазвичай викликають два види патогенних грибів, Dothistroma septosporum та Dothistroma pini. Дотистромоз хвої $є$ однією із найбільш важливих інвазійних хвороб сосни у багатьох країнах. Ця хвороба нещодавно виникла в Україні й була оцінена як основна загроза для сосни кримської (Pinus nigra subsp. pallasiana); для Pinus sylvestris вона $є$ менш загрозливою.

На сьогодні існують відомості, що грибні та бактеріальні ізоляти можуть зменшити ріст і патогенність грибів - збудників хвороб рослин. У цьому дослідженні інфіковані й неінфіковані хвоїнки зібрані у 30-річних насадженнях сосни кримської (P. nigra subsp. pallasiana) на півдні України. За допомогою фітопатологічних методів упродовж 20122014 рр. 3 хвої кримської сосни отримано 244 ізоляти ендофітних грибів, які використовували для аналізу їхньої антагоністичної активності.

Збудники дотистромозу (Dothistroma spp.) та потенційно перспективні для подальших експериментів грибні культури виявлені за допомогою ізоляції та застосування специфічних для виду методів полімеразної ланцюгової реакції.

Серед усіх ендофітів відібрано вісім видів грибів, які були спільними для всіх зразків і мали ознаки антагоністичної активності або раніше були визначені як антагоністи грибних захворювань рослин. Усі відібрані види протестовані на антигрибну активність стосовно дотистромозу (Dothistroma spp.) у чашках Петрі та на саджанцях сосни кримської у розсаднику. Найкращі показники антигрибної активності стосовно Dothistroma pini досягнуті під час використання грибів Trichoderma sp. та Gliocladium rosea. Це дає змогу припустити, що обидва види мають високий потенціал запобігання ураженню й поширенню дотистромозу, принаймні на молодих деревцях сосни. Значне зменшення кількості конідій збудника та пригнічення росту спор виявлено на хвоїнках, оброблених Trichoderma sp. та Gliocladium rosea у порівнянні з іншими видами грибів.

Хоча патоген D. pini присутній в Україні майже скрізь, де росте кримська сосна, важливо викорис-

\footnotetext{
Давиденко Катерина Валеріївна - член-кореспондент Лісівничої академії наук України, кандидат сільськогосподарських наук, старший науковий співробітник, доцент. Український науково-дослідний інститут лісового господарства та агролісомеліорації ім. Г.М. Висоцького, вул. Пушкінська, 86, Харків, 61024 , Україна. Запрошений науковий співробітник Департаменту Лісової мікології і фітопатології Шведського Аграрного Університету, Р.О. Вох 7026, SE-75007, Упсала, Швеція. Тел.: +38-09866755 26. E-mail: kateryna.davydenko74@gmail.com ORCID http://orcid.org/0000-0001-6077-8533
} 
товувати біологічні засоби контролю, які могли б зменшити вірулентність збудника дотистромозу або забезпечити стійкість рослини-живителя. Таким чином, використання ефективного біологічного контролю дотистромозу може бути корисним у лісових розсадниках, де важливо зменшити втрати від інфекції D. pini до висаджування кримської сосни в польові умови.

Ключові слова: Dothistroma septosporum; Dothistroma pini; патоген; біологічний контроль.

\section{Оценка использования грибов- эндофитов для биологического контроля дотистромоза сосны крымской (Pinus nigra subsp. pallasiana)}

\section{Е. В. Давиденко'}

Дотистромоз обычно вызывают два вида патогенных грибов, Dothistroma septosporum и Dothistroma pini. Дотистромоз хвои является одной из важнейших инвазивных болезней сосны во многих странах. Эта болезнь недавно распространилась в Украине и представляет угрозу преимущественно для сосны крымской (Pinus nigra subsp. pallasiana) и менее серьезную - для Pinus sylvestris.

Сегодня много исследований свидетельствуют о том, что некоторые грибные и бактериальные

\footnotetext{
Давиденко Екатерина Валерьевна - член-корреспондент Лесной академии наук Украины, кандидат сельскохозяйственных наук, доцент, старший научный сотрудник. Украинский научно-исследовательский институт лесного хозяйства и агролесомелиорации им. Г.Н. Высоцкого, ул. Пушкинская, 86, Харьков, 61024, Украина. Приглашенный научный сотрудник Департамента Лесной микологии и фитопатологии Шведского Аграрного Университета, Р.О. Box 7026, SE-75007, Упсала, Швеция. Tel.: +38-098 6675526. E-mail: kateryna.davydenko74@gmail.com ORCID http://orcid. org/0000-0001-6077-8533
}

изоляты могут снизить интенсивность роста и патогенность грибов - возбудителей болезней растений. Для тестирования потенциальных антагонистов дотистромоза, в 2012-2014 гг. собраны инфицированные и неинфицированные хвоинки с 30-летней крымской сосны (Р. nigra subsp. pallasiana) на юге Украины, и 244 вида эндофитных грибов проверены на возможную антигрибную активность. Возбудители дотистромоза (Dothistroma spp.) и потенциальные грибные антагонисты определены путем изоляции в чистую культуру и использования специфических видовых праймеров методом полимеразной цепной реакции.

Среди всех эндофитов отобрано восемь видов грибов, которые были общими для всех образцов и имели явные признаки антагонистической активности. Все отобранные виды протестированы на наличие противогрибной активности относительно дотистромоза (Dothistroma spp.) на 2-летних культурах сосны крымской. Лучшие показатели такой активности против Dothistroma pini достигнуты при использовании грибов Trichoderma sp. и Gliocladium rosea. Это позволяет предположить, что оба вида потенциально способны предотвратить распространение дотистромоза, по крайней мере, на молодых деревцах сосны. Значительное уменьшение количества конидий патогена и замедление прорастания спор выявлено на хвоинках, обработанных Trichoderma sp. и Gliocladium rosea, по сравнению с другими грибами. Хотя патоген D. pini присутствует в Украине везде, где растет крымская сосна, важно прилагать больше усилий, чтобы использовать биологические средства контроля, которые снижают вирулентность возбудителя дотистромоза или обеспечить устойчивость растения-хозяина. Таким образом, использование эффективного биологического контроля против дотистромоза может быть полезным в лесных питомниках, где важно уменьшить потери от инфекции D. pini до высадки крымской сосны в полевые условия.

Ключевые слова: Dothistroma septosporum; Dothistroma pini; патоген; биологический контроль. 